DOI 10.31651/2524-2660-2019-1-269-275

ORCID 0000-0001-9755-3645

\title{
YILDIRIM Ahmet,
}

Director of Esencay Middle School, Tasova, Amasya, Turkey;

PhD Student of Educational Administration, Bohdan Khmelnytsky National University at Cherkasy e-mail: aahmetyil25@gmail.com

\section{THE ANALYSIS OF SCHOOL MANAGERS' LEVELS OF EMOTIONAL INTELLIGENCE}

Abstract. Introduction. Many researches in recent years have focused on the role of emotions in working life. In this context, in order to ensure the success and happiness of the employees in the life, a certain level of Intelligence uotient-IQ-level, as well as the need to have emotional intelligence was put forward. Emotional intelligence includes emotional skills, such as emotional expression, emotion integration, and understanding of emotions. First, the industrial revolution, then technological developments and globalization, de communication, motivation, leadership, empathy, adaptation to change, continuous development, concepts such as a place in organizations and management has emerged as a business life. Since these concepts are elements of emotional intelligence, the main idea of the study is that the relationship between emotion and intelligence is the subject of both emotional intelligence and the historical development of the administration.

Purpose. This study mainly aims to determine school managers' levels of emotional intelligence (three dimensions of emotional intelligence: selfawareness of emotions, expressing emotions and sympathizing with others' emotions).

Method. The present study benefits from descriptive survey model which aims to describe a situation in the past or a currently existing situation under its own conditions. The population of the study consists of school managers working in Amasya province of Turkey. The sample of the study consists of 69 school managers working in Taşova district of Amasya province. The questionnaire developed by Robert Cooper and Ayman Sawaf was used as a data collection tool, which is limited to managers' three abilities related to emotional intelligence.

Conclusion. According to the results of the study conducted to examine the level of emotional intelligence of school administrators, it is seen that the school administrators have reached the best level in the sub-dimension of expressing their emotions, which are three dimensions of emotional intelligence. Accordingly, school administrators have no problem in expressing their feelings. It is observed that they have reached the advanced level according to the awareness of their feelings and awareness of others' feelings.

Keywords: Feeling; Intelligence; Emotional Intelligence; Emotional Intelligence Level.

\section{INTRODUCTION}

In the first half of $20^{\text {th }}$ century, in addition to its role in an individual's success, cognitive intelligence was considered as the most fundamental type of intelligence whose performance cannot be envisaged. Along with various success criteria, several studies focused on the analysis of the impact of intelligence on leadership, and demonstrated that cognitive intelligence was strongly tied with leadership [1]. However, in the $21^{\text {st }}$ century, constantly changing environmental and professional conditions caused remarkable differences in the definitions of leadership and intelligence. As a result of scientific developments and social events that occurred in the Northern America and Europe during the 1960s, the absolute power of intelligence started to be questioned, and the role of emotions in professional life was discussed [2]. Thus, Mayer and Salovey [3] introduced the notion of emotional intelligence and argued that this concept could explain an employee's performance in a situation more efficiently compared to cognitive intelligence [4].

\section{Emotional Intelligence}

Dökmen [5] states that emotions function as a tool for individuals to adapt to the nature and society. Similarly, Goleman [6] define emotions as traits which trigger an individual's potential to learn, encourage them to question and seek answers to their questions, increase their capacity and help them practice what they learn in order to maintain an attitude towards a situation. According to Cooper and Sawaf [7], emotions are sources of energy which motivate an individual's inner values and shape their behaviors, thus being emitted to other individuals and influencing them. Erik Erikson, a well-known psychoanalyst, defines emotional intelligence as the ability to integrate various personal traits successfully and calls it the integrity of selfness [8]. A study on adults reports that fields of intelligence which help various species become mature are linguistic, logicalmathematical, visual-spatial, musical, bodily-kinesthetic, personal and interpersonal intelligence [9].

Emotions are the organizers of thinking and action. In addition, although emotions sometimes seem to contradict with each other, individuals need them to judge something and behave rationally. Emotional intelligence greatly helps academic intelligence when the individual aims to offer solution to a problem or make an important decision, and enable them to do these in a more qualified manner and a 
short time. In other words, it can be argued that emotional intelligence bears importance in terms of judgement and academic intelligence [10]. On the other hand, it is possible to gain emotional intelligence through learning instead of hereditary traits, which makes it possible to improve emotional intelligence [11].

Various studies on emotional intelligence in the last 10 years demonstrate that the difference between a distinguished and a moderate level of performance is largely related to emotional intelligence [12].

The following emotional traits can be listed as the contributors to emotional intelligence [13]:

- The ability to empathize and build emphatic relationships,

- The ability to express and understand emotions, tions,

- The ability to control one's disposi-

- The ability to act independently,

- The ability to adapt to one's environment,

- Seeking approval,

- The ability to solve a problem in interpersonal relationships,

- Patience and determination,

- The ability to sympathize,

- Respect.

Goleman [6] maintains the idea that emotional intelligence can be used as a criterion for the measurement of human intelligence and that it is necessary for success, and adds that emotional intelligence may help an individual be promoted to higher ranks in their professional life. Cooper and Sawaf [7], too, state that different studies reached similar conclusions on emotional intelligence and argue that it gives the energy to perform reliable and profitable business relations thanks to its relationship with moral values such as trust, integrity, empathy, flexibility and reliability. Baltas [14] shares this view and argues that the best performances are displayed by individuals who can build healthy relationships with their coworkers, can contribute to team work and have a higher level of emotional maturity instead of those with a high level of academic intelligence.

Numerous studies revealed the importance of emotional intelligence for a manager in terms of organizational success. For instance, Pamukoğlu [15] reports a highly positive correlation between manager effectiveness and emotional intelligence scores. In a similar vein, different studies indicated that a positive correlation was found between managers' emotional intelligence and levels of burnout [16], that there was a positive correlation between emotional intelligence and all dimensions of transformational leadership [17], that a positive correlation was observed between a manager's emotional intelligence and human-oriented leadership behaviors [18], that a strongly positive correlation was found out between primary school principals' emotional intelligence and teachers' job satisfaction and principals' emotional intelligence influenced teachers' job satisfaction positively [19], that vice principals' levels of emotional intelligence heavily influenced teachers' organizational citizenship behaviors, job satisfaction and levels of emotional commitment [20], that a positive correlation was found between managers' emotional intelligence and their human-oriented leadership behaviors [21], that a highly positive correlation was observed between primary school principals' educational leadership behaviors and levels of emotional intelligence [22], that secondary school principals' levels of emotional intelligence were closely related to school performance [23], and that there was a positive and significant correlation between school principals' transformational leadership behaviors and their levels of use of personal abilities which is one of the dimensions of emotional intelligence [24]. Therefore, it is clear that managers' levels of emotional intelligence play an active role in the organizational communication process [25]. Schmidt [26] also states that emotional intelligence is becoming more and more important for today's managers as numerous changes occur in professional life in the new millennium. In addition, it was also found out that a moderately significant positive correlation was observed bretween employees' levels of emotional intelligence and job satisfaction [27].

\section{THE OBJECTIVE OF THE STUDY}

This study mainly aims to determine school managers' levels of emotional intelligence (three dimensions of emotional intelligence: self-awareness of emotions, expressing emotions and sympathizing with others' emotions).

\section{METHOD}

The present study benefits from descriptive survey model which aims to describe a situation in the past or a currently existing situation under its own conditions. It attempts to objectively describe an individual or object under question without any modification or influence on them [28]. Therefore, this model was preferred to 
measure school managers' levels of emotional intelligence.

The population of the study consists of school managers working in Amasya province of Turkey. The sample of the study consists of 69 school managers working in Taşova district of Amasya province. The questionnaire developed by Robert Cooper and Ayman Sawaf was used as a data collection tool, which is limited to managers' three abilities related to emotional intelligence.

The questionnaire consists of two parts. While 4 questions are asked regarding managers' personal information in the first part, 33 behaviors in three dimensions are defined in order to measure school managers' levels of emotional intelligence in the second part. Among these behaviors, those in 1-11 are related to self-awareness of emotions, those in 12-20 are related to expressing emotions, and those in 21-33 are related to sympathizing with other people's emotions. For the data analysis, negative behaviors in the $6^{\text {th }}, 8^{\text {th }}, 9^{\text {th }}, 18^{\text {th }}, 20^{\text {th }}$, $22^{\text {nd }}$ and $24^{\text {th }}$ questions are scored as never (3), sometimes (2), usually (1) and always (0) depending on their frequency. Similarly, other behaviors are scored as never (0), sometimes (1), usually (2) and always (3) depending on their frequency. Four degrees of performance given in Table 1 were used for evaluation.

Table 1

Four Degrees of Performance

\begin{tabular}{|l|c|c|c|c|}
\hline \multicolumn{1}{|c|}{ Dimensions } & Careful & Sensitive & Advanced & Best \\
\hline Self-awareness of emotions & $0-18$ & $19-23$ & $24-28$ & $29-33$ \\
\hline Expressing emotions & $0-12$ & $13-16$ & $17-19$ & $20-27$ \\
\hline Sympathizing with others' emotions & $0-14$ & $15-21$ & $22-27$ & $28-39$ \\
\hline
\end{tabular}

According to Table 1, at the best level, an individual has a quite high level of emotional intelligence and can stay strong even under high pressure without losing their abilities such as creativity and influence. At the advanced level, the individual can be said to have a continuous and balanced level of emotional intelligence in most situations. At the sensitive level, the individual's level of emotional intelligence displays irregularities in terms of their abilities and skills, and thus may vary from one situa- tion to the other. At the careful level, the individual faces difficulties because of a low level of emotional intelligence and concentration on a topic, which often results in failure.

\section{FINDINGS}

In this part of the research, the findings obtained from the analysis are given. The personal information of the managers within the scope of the research is shown in Table 2.

Table 2

Demographic Information of Participants

\begin{tabular}{|c|c|c|c|}
\hline Personel Details & & $\mathbf{f}$ & $\%$ \\
\hline \multirow{2}{*}{ Gender } & Female & 17 & 24,6 \\
\hline & Male & 52 & 75,4 \\
\hline \multirow{4}{*}{ Age } & $21-30$ & 10 & 14,5 \\
\hline & $31-40$ & 45 & 65,2 \\
\hline & $41-50$ & 6 & 8,7 \\
\hline & 51 and older & 8 & 11,6 \\
\hline \multirow{4}{*}{ Length of Service } & $1-5$ & 32 & 46,4 \\
\hline & $6-10$ & 18 & 26,1 \\
\hline & $11-20$ & 16 & 23,2 \\
\hline & 21 and older & 3 & 4,3 \\
\hline \multirow{3}{*}{ Education Level } & College & 3 & 4,3 \\
\hline & Licence & 55 & 79,7 \\
\hline & Postgraduate & 11 & 15,9 \\
\hline
\end{tabular}

According to Table 2, 17 (24.6\%) of the participants were female and 52 (75.4\%) were male. $10(14.5 \%)$ of the participants were between the ages of 21-30, 45 (65.2\%) were between $31-40$ years old, $6(8.7 \%)$ were between 41-50 years old and 8 $(11,6 \%)$ is 51 years and over. According to the length of service of the participants, 32 $(46.4 \%)$ were between 1-5 years, 18 $(26.1 \%)$ were between $6-10$ years, and 16 
$(23.2 \%)$ were between $11-20$ years and 3 $(4.3 \%)$ are over 21 years and over. $3(4.3 \%)$ of the participants were graduated from college, $55(79.7 \%)$ of them were licence and $11(15.9 \%)$ of them were postgraduate.

The results of the responses given by the managers to the frequency of their be- haviors regarding the awareness of their feelings, expressing their feelings and showing the ways of behaving about the dimensions of others ' feelings are presented in Table 3.

Frequency and Percentage Distributions Showing Behavior Patterns

\begin{tabular}{|c|c|c|c|c|c|c|c|c|c|c|c|c|}
\hline \multirow{3}{*}{\multicolumn{2}{|c|}{ Items }} & \multicolumn{8}{|c|}{ Degree of Attendance } & \multirow{3}{*}{$\bar{x}$} & \multirow{3}{*}{ Point } & \multirow{3}{*}{ Degree } \\
\hline & & \multicolumn{2}{|c|}{ Never } & \multicolumn{2}{|c|}{$\begin{array}{c}\text { Occasional } \\
\text { ly }\end{array}$} & \multicolumn{2}{|c|}{ Usually } & \multicolumn{2}{|c|}{ Always } & & & \\
\hline & & $\mathbf{f}$ & $\%$ & $\mathbf{f}$ & $\%$ & $\mathbf{f}$ & $\%$ & $\mathbf{f}$ & $\%$ & & & \\
\hline 1 & I can describe my feelings. & - & - & 5 & 7,2 & 5 & 7,2 & 59 & 85,5 & 2,78 & 30,58 & Best \\
\hline 2 & $\begin{array}{l}\text { I can recognize myself by } \\
\text { moving senses. }\end{array}$ & - & - & 2 & 2,9 & 1 & 1,4 & 66 & 95,7 & 2,93 & 32,23 & Best \\
\hline 3 & $\begin{array}{l}\text { I can be aware of my feel- } \\
\text { ings. }\end{array}$ & - & - & - & - & 7 & 10,1 & 62 & 89,9 & 2,90 & 31,90 & Best \\
\hline 4 & $\begin{array}{l}\text { I can understand that I'm } \\
\text { starting to feel sorry. }\end{array}$ & - & - & 1 & 1,4 & 9 & 13,0 & 59 & 85,5 & 2,84 & 31,24 & Best \\
\hline 5 & $\begin{array}{l}\text { I can understand the } \\
\text { reasons for my sorrow. }\end{array}$ & - & - & - & - & 12 & 17,4 & 57 & 82,6 & 2,83 & 31,13 & Best \\
\hline 6 & $\begin{array}{l}\text { I can judge myself from } \\
\text { the point of view of others. }\end{array}$ & 42 & 60,9 & 24 & 34,8 & 2 & 2,9 & 1 & 1,4 & 0,45 & 4,95 & Careful \\
\hline 7 & I enjoy my emotional life. & 4 & 5,8 & 9 & 13,0 & 20 & 29,0 & 36 & 52,2 & 2,28 & 25,08 & $\begin{array}{c}\text { Ad- } \\
\text { vanced }\end{array}$ \\
\hline 8 & $\begin{array}{l}\text { People who expose their } \\
\text { feelings scare me. }\end{array}$ & 8 & 11,6 & 30 & 43,5 & 10 & 14,5 & 21 & 30,4 & 1,64 & 18,04 & Sensitive \\
\hline 9 & I want to be someone else. & 9 & 13,0 & 13 & 18,8 & 15 & 21,7 & 32 & 46,4 & 2,01 & 22,11 & Sensitive \\
\hline 10 & $\begin{array}{c}\text { I take care of my physical } \\
\text { condition to understand } \\
\text { my feelings. }\end{array}$ & 1 & 1,4 & 13 & 18,8 & 13 & 18,8 & 42 & 60,9 & 2,39 & 26,29 & $\begin{array}{c}\text { Ad- } \\
\text { vanced }\end{array}$ \\
\hline 11 & $\begin{array}{l}\text { I accept responsibility for } \\
\text { my feelings. }\end{array}$ & - & - & 3 & 4,3 & 10 & 14,5 & 56 & 81,2 & 2,77 & 30,47 & Best \\
\hline 12 & I praise successful people. & 4 & 5,8 & 2 & 2,9 & 8 & 11,6 & 55 & 79,7 & 2,65 & 29,15 & Best \\
\hline 13 & I can express my feelings. & - & - & 5 & 7,2 & 12 & 17,4 & 52 & 75,4 & 2,68 & 29,48 & Best \\
\hline 14 & $\begin{array}{l}\text { I can tell others my wishes } \\
\text { and needs. }\end{array}$ & 1 & 1,4 & 4 & 5,8 & 25 & 36,2 & 39 & 56,5 & 2,48 & 27,28 & Best \\
\hline 15 & $\begin{array}{l}\text { My friends tell me that I've } \\
\text { exposed my good thoughts } \\
\text { about them. }\end{array}$ & 2 & 2,9 & 8 & 11,6 & 21 & 30,4 & 38 & 55,1 & 2,38 & 26,18 & Best \\
\hline 16 & $\begin{array}{l}\text { I keep my feelings to my- } \\
\text { self. }\end{array}$ & 20 & 29,0 & 30 & 43,5 & 16 & 23,2 & 3 & 4,3 & 1,03 & 11,33 & Careful \\
\hline 17 & $\begin{array}{l}\text { I explain my feelings that } \\
\text { make me feel uneasy with- } \\
\text { in the group. }\end{array}$ & 2 & 2,9 & 20 & 29,0 & 28 & 40,6 & 19 & 27,5 & 1,93 & 21,23 & $\begin{array}{c}\text { Ad- } \\
\text { vanced }\end{array}$ \\
\hline 18 & $\begin{array}{l}\text { I have a hard time explain- } \\
\text { ing my need for help. }\end{array}$ & 19 & 27,5 & 28 & 40,6 & 16 & 23,2 & 6 & 8,7 & 1,13 & 12,43 & Careful \\
\hline 19 & $\begin{array}{l}\text { I can sense what people } \\
\text { I'm communicating with. }\end{array}$ & 1 & 1,4 & 4 & 5,8 & 18 & 26,1 & 46 & 66,7 & 2,58 & 28,38 & Best \\
\hline 20 & $\begin{array}{l}\text { I can do anything not to } \\
\text { look ridiculous to my } \\
\text { friends. }\end{array}$ & 16 & 23,2 & 14 & 20,3 & 11 & 15,9 & 28 & 40,6 & 1,74 & 19,14 & $\begin{array}{l}\text { Ad- } \\
\text { vanced }\end{array}$ \\
\hline 21 & I can see how others feel. & 1 & 1,4 & 7 & 10,1 & 29 & 42,0 & 32 & 46,4 & 2,33 & 25,63 & Best \\
\hline 22 & $\begin{array}{c}\text { I have a hard time talking } \\
\text { to people who share my } \\
\text { opinion. }\end{array}$ & 13 & 18,8 & 17 & 24,6 & 16 & 23,2 & 23 & 33,3 & 1,71 & 18,81 & Sensitive \\
\hline 23 & $\begin{array}{l}\text { I act according to the } \\
\text { positive characteristics of } \\
\text { people. }\end{array}$ & 3 & 4,3 & 11 & 15,9 & 21 & 30,4 & 34 & 49,3 & 2,25 & 24,75 & $\begin{array}{c}\text { Ad- } \\
\text { vanced }\end{array}$ \\
\hline 24 & $\begin{array}{l}\text { I hit people's mistakes in } \\
\text { their faces. }\end{array}$ & 4 & 5,8 & 22 & 31,9 & 18 & 26,1 & 25 & 36,2 & 1,93 & 21,23 & Sensitive \\
\hline 25 & $\begin{array}{l}\text { Before I explain my views, } \\
\text { I think how others will } \\
\text { feel. }\end{array}$ & 3 & 4,3 & 8 & 11,6 & 30 & 43,5 & 28 & 40,6 & 2,20 & 24,20 & $\begin{array}{c}\text { Ad- } \\
\text { vanced }\end{array}$ \\
\hline 26 & I'm a good listener. & 3 & 4,3 & - & - & 11 & 15,9 & 55 & 79,7 & 2,71 & 29,81 & Best \\
\hline 27 & $\begin{array}{l}\text { I can understand the } \\
\text { mood of the group I've } \\
\text { met. }\end{array}$ & 1 & 1,4 & 1 & 1,4 & 21 & 30,4 & 46 & 66,7 & 2,62 & 28,82 & $\begin{array}{l}\text { Ad- } \\
\text { vanced }\end{array}$ \\
\hline 28 & $\begin{array}{c}\text { I can talk about people I } \\
\text { just met. }\end{array}$ & 3 & 4,3 & 7 & 10,1 & 22 & 31,9 & 37 & 53,6 & 2,35 & 25,85 & $\begin{array}{c}\text { Ad- } \\
\text { vanced }\end{array}$ \\
\hline 29 & When someone is talking, I & 1 & 1,4 & 6 & 8,7 & 16 & 23,2 & 46 & 66,7 & 2,55 & 28,05 & Ad- \\
\hline
\end{tabular}




\begin{tabular}{|c|c|c|c|c|c|c|c|c|c|c|c|c|}
\hline & $\begin{array}{c}\text { can understand what you } \\
\text { want to imply. }\end{array}$ & & & & & & & & & & & vanced \\
\hline 30 & $\begin{array}{c}\text { I can understand how } \\
\text { others feel about me. }\end{array}$ & 1 & 1,4 & 8 & 11,6 & 18 & 26,1 & 42 & 60,9 & 2,46 & 27,06 & $\begin{array}{c}\text { Ad- } \\
\text { vanced }\end{array}$ \\
\hline 31 & $\begin{array}{c}\text { Even if he doesn't say it, I } \\
\text { can understand someone } \\
\text { else's feelings. }\end{array}$ & 1 & 1,4 & 5 & 7,2 & 20 & 29,0 & 43 & 62,3 & 2,52 & 27,72 & $\begin{array}{c}\text { Ad- } \\
\text { vanced }\end{array}$ \\
\hline 32 & $\begin{array}{c}\text { I'm revealing my feelings } \\
\text { depends on the person I'm } \\
\text { with. }\end{array}$ & 3 & 4,3 & 2 & 2,9 & 10 & 14,5 & 54,3 & 78,3 & 2,67 & 29,37 & $\begin{array}{c}\text { Ad- } \\
\text { vanced }\end{array}$ \\
\hline 33 & $\begin{array}{c}\text { I can understand that } \\
\text { those around me are trou- } \\
\text { bled. }\end{array}$ & 2 & 2,9 & - & - & 14 & 20,3 & 53 & 76,8 & 2,71 & 29,81 & $\begin{array}{c}\text { Ad- } \\
\text { vanced }\end{array}$ \\
\hline
\end{tabular}

According to Table 3 , the behaviors that define the dimension of being aware of the emotions of the managers are at the best level according to the evaluation scale given in Table 1 , in the $1^{\text {st }}, 2^{\text {nd }}, 3^{\text {rd }}, 4^{\text {th }}, 5^{\text {th }}$ and $11^{\text {th }}$ positions, in the $7^{\text {th }}$ and $10^{\text {th }}$ rank behaviors at the advanced level, $8^{\text {th }}$ and $9^{\text {th }}$ behaviors are at a sensitive level.

$6^{\text {th }}$, "I can judge myself from the perspectives of others" behavior is realized on the same scale at the level of attention, and it is understood that participants are unable to judge themselves from the perspectives of others.

According to Table 3, managers to express their feelings, behaviors, defining the size, $12^{\text {th }}, 13^{\text {th }}, 15^{\text {th }}, 19^{\text {th }}$, and $21^{\text {st }}$ according to the evaluation scale given in Table 1 , the next behaviors are at the best level, $14^{\text {th }}, 17^{\text {th }}$ and $20^{\text {th }}$ the next behavior is seen to be advanced.

$16^{\text {th }}$ next is "I keep my feelings to myself", $18^{\text {th }}$ the next "I find it difficult to explain my need for help" behavior has been realized at the level of attention on the same scale. According to this, it is observed that the participants opened their feelings to their heads and expressed their need for help in a normal way. $22^{\text {nd }}$ he next "I have difficulty talking to people who share my opinion" behavior seems to be at the same level of sensitivity.

According to Table 3; behaviors that define the dimension of being aware of the feelings of others are observed to be at an advanced level according to the evaluation scale given in Table 1 of the $23^{\text {rd }}, 25^{\text {th }}, 27^{\text {th }}$, $28^{\text {th }}, 29^{\text {th }}, 30^{\text {th }}, 31^{\text {st }}, 32^{\text {nd }}$ and $33^{\text {rd }}$ behaviors.

24th the next "I hit others 'mistakes in their faces" behavior takes place at the same level of precision, according to the same scale, and it can be said that participants are sensitive when they say others' mistakes. $26^{\text {th }}$ the next "I am a good listener" is the best one on the same scale, and it can be said that the participants are always a good listener.

The average, scores and levels of the school administrators 'awareness of their feelings, expressing their feelings and awareness of others' feelings are presented in Table 4.

Average, Score and Level Information About Sub-dimensions

\begin{tabular}{|c|c|c|c|}
\hline Dimensions & Mean & Point & Degree \\
\hline Self-awareness of emotions & 2,34 & 25,74 & Advance \\
\hline Expressing emotions & 2,05 & 22,55 & The Best \\
\hline Sympathizing with others' emotions & 2,45 & 26,85 & Advance \\
\hline
\end{tabular}

As can be seen in Table 4, the average of the managers' awareness of the emotions and the awareness of the emotions of others and the corresponding scores are at the advanced level according to the evaluation scale given in Table 1 , and at the best level in terms of expressing the feelings, They can be interpreted as having a continuous and balanced level of emotional intelligence.

\section{CONCLUSIONS AND DISCUSSION}

According to the results of the study conducted to examine the level of emotion- al intelligence of school administrators, it is seen that the school administrators have reached the best level in the subdimension of expressing their emotions, which are three dimensions of emotional intelligence. Accordingly, school administrators have no problem in expressing their feelings. It is observed that they have reached the advanced level according to the awareness of their feelings and awareness of others' feelings. According to this, managers have been found to have a continuous and balanced level of emotional 
intelligence in many cases, being aware of their emotions and being aware of others' feelings.

Similar studies are important in other dimensions of emotional intelligence, as well as in managers and other employees in different business environments and different research universes, as it will allow comparison of results.

It can be expressed as another suggestion that the organizations of the organizations providing formal education and the inservice training programs, emotions, emotion management and emotional intelligence issues should be included.

\section{References}

1. Mandell, B., Pherwani, S. (2003). Relationship between Emotional Intelligence and Transformational Leadership Style. Journal of Business and Psychology. 17(2):387-404.

2. Çakar, U. and Arbak, Y. (2003). Changing EmotionIntelligence Relationship and Emotional Intelligence in the Light of Modern Approaches. Unpublished Work.

3. Mayer, J. D. and Salovey, P. (1993) The Intelligence of Emotional Intelligence. Intelligence. 17: 433-442.

4. Lam, L.T. \& Kirby, S.L. (2002) Is Emotional Intelligence an Advantage? An Exploration of the Impact of Emotional and General Intelligence on Individual Performance. The Journal of Social Psychology. 142(1):133-143.

5. Dökmen, Ü. (2000). Consolidate Develop. System Publishing. Istanbul.

6. Goleman, D. (1998). Emotional Intelligence. 3.Printing. Trans. B. S. High. Asset Publications. Istanbul.

7. Cooper, R. and Sawaf, A. (1999). Emotional Intelligence In Leadership. Trans. Z.B. Ayman and B. Sancar. System Publishing. Istanbul.

8. James, J. (1997). The Next Time You Think About It. Trans. Z. Dicleli. Boyner Holding Publications. Istanbul.

9. Healy, J., M. (1999). Your Child's Developing Mind. Çev: A.B. Dicleli. Boyner Holding Publications. Istanbul.

10. Cooper, R. K. and Sawaf, A. (2000). Emotional intelligence in leadership. Istanbul: Sistem Publishing.

11. Clark, L. (2000). Help with emotions. (Translated by Gültekin Yazgan). Istanbul: Evrim Publishing House.

12. Thomas, M., A. (2004), "Understanding Emotional Intelligence Can Help Alter Problem Behavior", Physician Executive.

13. Güney, S. (2000). Behavioral Sciences. Nobel Publishing House, Ankara.
14. Baltaş, A. (2000). Emotional Intelligence of Companies Gives High Energy. Beko News Magazine. Issue: 21.

15. Pamukoğlu, E. (2004). Investigation of the role of emotional intelligence in executive activity in the context of female managers and research. Unpublished master thesis, Kocaeli University.

16. Güllüce, A. C. (2006). Relationship between occupational burnout and emotional intelligence. Unpublished master's thesis, Atatürk University.

17. Sahin, F. (2006). The relationship of emotional intelligence with effective leadership behaviors: A study on officers and non-commissioned officers working in Kayseri Military Service Department. Unpublished master thesis, Balikesir University.

18. Acar, F. (2002). Emotional intelligence and leadership. Erciyes University Journal of Social Sciences Institute. 12, pp.53-68.

19. Turanl1, A. (2007). Emotional intelligence of primary school principals and job satisfaction levels of teachers. Unpublished doctoral dissertation, Dokuz Eylül University.

20. Karakuş, M. (2008). The effect of primary school administrators and teachers 'emotional intelligence competencies on teachers' emotional commitment, organizational citizenship and job satisfaction levels. Unpublished doctoral dissertation, Firat University.

21. Acar, F. T. (2001). The relationship between emotional intelligence skills and task-oriented leadership behavior. Unpublished doctoral thesis, Istanbul University.

22. Tikır, N. (2005). Examining the relationship between primary school principals' instructional leadership behavior and emotional intelligence. Unpublished master's thesis, Gaziantep University.

23. Bardach, R. H. (2008). Leading schools with emotional intelligence: A study of the degree of association between middle school principal emotional intelligence and school success. Unpublished doctora dissertation, Capella University.

24. Ergin, D. (2008). Teachers' perceptions of emotional intelligence and transformational leadership in school management. Unpublished master thesis, Kocaeli University.

25. Tuna, Y. (2008). Emotional intelligence competencies of managers in organizational communication process. Unpublished doctoral thesis, Anadolu University.

26. Canbulat, S. (2007). To investigate the effect of emotional intelligence on job satisfaction of employees. Unpublished master thesis, Gazi University.

27. Trucker, M. L., Sojka, J. Z., Barone, F. J. and Mccarthy, A. M. (2000). Training tomorrow's leaders: Enhancing the emotional intelligence of business graduates. Journal of Education for Business. 75(6), 331-7.

28. Karasar, N. (2005). Scientific research method (17th edition). Ankara: Nobel publication distribution, 81-83.

йиАдиРИМ Ахмет,

директор середньої школи в Есенсе, Тасова, Амасья, Туреччина; аспірант, Черкассскій національний університет імені Богдана Хмельницького

\section{АНААИЗ УРОВНЕЙ ЭМОЦИОНААЬНОГО ИНТЕААЕКТА ШКОАЬНЫХ МЕНЕДЖЕРОВ}

Аннотаиия. Вступление. Многие исследования последних лет были сосредоточены на роли эмоиий в трудовой жизни. В этом контексте, чтобы обеспечить успех и счастье сотрудников в жизни, был выдвинут определенный уровень интеллекта IQ-level, a также необходимость иметь эмоииональный интеллект. Эмоииональный интеллект включает в себя эмоииональные навыки, такие как эмоииональное выражение, интеграиия эмочий и понимание эмоиий.
Сначала промышленная революиия, затем технологическое развитие и глобализаиия, коммуникаиия, мотиваиия, лидерство, сочувствие, адаптаиия $\kappa$ изменениям, постоянное развитие, такие кониепиии, как место в организаииях и управлении, стали деловой жизнью. Поскольку эти понятия являются элементами эмоиионального интеллекта, основная идея исследования заключается в том, что отношения между эмоииями и интеллектом являются предме- 
том как эмоиионального интеллекта, так и исторического развития администраиии.

Цель. Это исследование в основном направлено на определение уровней эмоиионального интеллекта руководителей школ (три измерения эмоиионального интеллекта: самосознание эмоиий, выражение эмоиий и сочувствие эмоииям других).

Метод. В настояшем исследовании используется модель описательного опроса, иелью которой является описание ситуаиии в прошлом или существуюшей в настоящее время ситуаиии в ее собственных условиях. Население исследования состоит из руководителей школ, работающих в провиниии Амасья в Туриии. Выборка исследования состоит из 69 руководителей школ, работающих в Ташовском районе провиниии Амасъя. Анкета, разработанная Робертом Купером и Айманом Савафом, использовалась в качестве инструмента сбора данных, кото- рый ограничен тремя способностями менеджеров, связанньми с эмоииональным интеллектом.

Заключение. Согласно результатам исследования, проведенного с иелью изучения уровня эмоционального интеллекта школьных администраторов, видно, что школьные администраторы достигли наилучшего уровня в том измерении выражения своих эмоиий, которое является тремя измерениями эмоционального интеллекта. Соответственно, у школьных администраторов нет проблем с выражением своих чувств. Наблюдается, что они достигли продвинутого уровня в соответствии с осознанием своих чувств и осознанием чувств других.

Ключевые слова: чувство; интеллект; эмоииональный интеллект; уровень эмоиионального интеллекта.

Одержано редакиією 21.01.2019 Прийнято до публікаиії 26.01.2018

DOI 10.31651/2524-2660-2019-1-275-279

ORCID 0000-0001-6015-9492

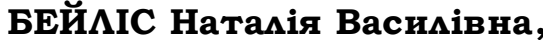

аспірант кафедри педагогіки та управління освітою, Донецький національний університет імені Василя Стуса e-mail: beylisnv@ukr.net

УДК 37.091.33:811.112.2:373.5(477)

\section{ПЕРСПЕКТИВИ ОНОВАЕННЯ ВИВЧЕННЯ УЧНЯМИ ЗМІСТУ НІМЕЦЫКОЇ МОВИ НА ЕТНОКУАЬТУРНОМУ ПIДГРУНТІ}

у статті робиться акиент на тому, шо одним з найважливіших векторів розвитку сучасної освіти є оновлення вивчення змісту іноземних мов за допомогою впровадження нових прогресивних методів навчання в сучасній школі. Також враховуються застосування етнокультурного знання як засобу навчання на уроках німеиької мови в школах України в сучасних реаліях.

Особлива увага приділяеться створенню спеиіального комплексу нових способів діяльності у змісті іншомовної (німеиької) освіти, який вимагає реалізаиї уже в близькій перспективі та е актуальним

Крім иього, провідним аспектам наукового дискурсу в наш час в контексті використання етнознань в освіті у вимірах входження України в загальноєвропейський освітній простір має надзвичайно велике значення. Воно інтегрує проиеси, які не можна об'єднати в межах класичної освіти.

ключові слова: іноземні мови; німецька мова; етнокультурні матеріали; етнокультурне підтрунтя; етнознання; етнокультурне середовише.

Постановка пробиеми. За роки незалежності України етнокуцьтурний компонент з'явився у навчамьно-виховному процесі вивчення іноземних мов (у контексті змісту, форм і методів, навчальновиховного середовища).

Водночас навчамьна дисципліна “німецька мова" має значний етнокультурний освітній та виховний потенціал, який у практиці недостатньо реалізується.

Це підтверджується загальними тенденціями педагогічних реалій, а також можна стверджувати, що учні у процесі вивчення німецької мови не виявляють достатньої готовності брати участь в міжкультурній комунікації, поділяти цінності іншомовної культури та презентувати свою національну культуру. Все це свідчить про те, що рівень якості знань 3 німецької мови учнями загальноосвітніх шкіл не є цілком задовільний.

Актуальність даної теми можна обгрунтувати вемиким попитом на оновмення вивчення змісту іноземних мов за допомогою впровадження етнознань як нових прогресивних методів навчання іноземних мов в сучасній шкомі. Питання організації наближеного етнокультурного середовища в навчальному процесі іноземних мов відносяться в даний час до числа актуальних проблем іншомовної освіти загальноосвітньої школи.

Навчання 3 використанням етнокультурних матеріалів на уроках німецької мови полегшує орієнтацію школярів в середовищі, наближеному до німецькомовного, а значить, сприяє адаптації учнів до кумьтури німецькомовних країн. 